
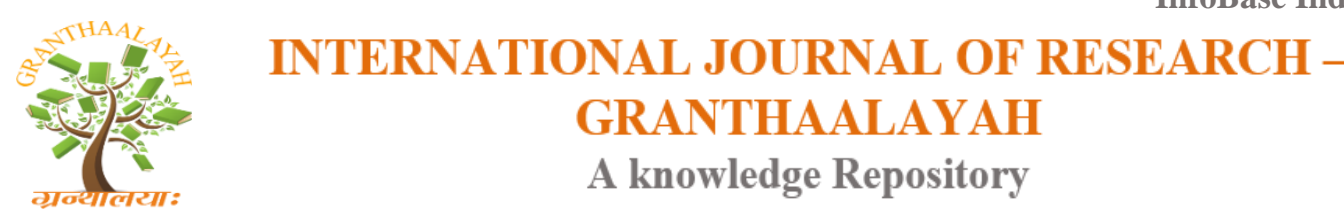

Management

\title{
THE IMPORTANCE OF DIGITAL MARKETING IN THE TOURISM INDUSTRY
}

\author{
Gurneet Kaur ${ }^{* 1}$ \\ ${ }^{* 1}$ Department of Commerce, Sri Guru Nanak Dev Khalsa College, Delhi University, India
}

DOI: https://doi.org/10.29121/granthaalayah.v5.i6.2017.1998

\begin{abstract}
With the advent of superior Internet technologies, newer avenues for reaching out to target audiences have evolved. Digital marketing today has become an indispensable part of every business irrespective of its size and type. The increasing role of digital marketing has affected the way businesses promote their offerings to existing as well as new customers. The need for digital marketing has been felt like never before in the tourism industry wherein customers have instant access to all kinds of information on the latest offers and best prices. Today digital marketing plays a critical role in the success of each business which exists in the tourism industry. This paper examines the basic determinants of digital marketing and the importance of the same in the tourism industry.
\end{abstract}

Keywords: Digital Marketing; Internet Marketing; Tourism; Websites; SEO; Email Marketing; Social Media.

Cite This Article: Gurneet Kaur. (2017). "THE IMPORTANCE OF DIGITAL MARKETING IN THE TOURISM INDUSTRY." International Journal of Research - Granthaalayah, 5(6), 72-77. https://doi.org/10.29121/granthaalayah.v5.i6.2017.1998.

\section{Introduction}

With the launch of internet technology, the rules of marketing have been redefined all over the world. The internet has upended how consumers engage with brands. It is transforming the economics of marketing and making obsolete many of the function's traditional strategies and structures. For marketers, the old way of doing business is unsustainable (Edelman, 2010).Digital Marketing today has become the one of the key focus areas for businesses all over the world. It started as a mode of communication and has evolved not just into another source of additional revenue but most importantly, to develop and maintain long-term relationships with the various parties in the market. Interactivity, as the main feature of the Internet, has enabled a new dimension of connection between all the participants in the market (Batinić, 2015). Internet users today interact not just with each other but also with their preferred brands. This has opened an opportunity for brands to talk directly with their users and to know them better. 
One of the main reasons of the success of digital marketing vs. traditional marketing is the fact that the former allows businesses to track user behaviour in real-time. Every campaign launched digitally can be tracked in terms of its reach, engagement and conversion. This has given a whole new meaning to the marketing research to understand the needs of the customers like never before. Thus, the need to include digital marketing in the overall marketing strategy of the business shall only contribute to the better achievement of the overall marketing and business goals by enabling brands to gain insights about consumer behaviour and better satisfy their needs.

\section{Understanding Digital Marketing}

After reviewing the several literatures available on the subject, the meaning of digital marketing can be understood better.

- Internet marketing and online advertising, also called e-marketing, web marketing, online marketing, or e-marketing, is the advertising of products and services over the Internet. (Ruzic, D. 2003).

- "The application of the Internet and related digital technologies in conjunction with traditional communications to achieve marketing objectives." (Chaffey, 2012)

- Internet marketing is the use of the Internet and other digital technologies with traditional methods in order to achieve marketing goals. Marketing using electronic media such as the web, email, interactive TV, IPTV and wireless media in conjunction with digital data about customers characteristics \& behaviors. (Chaffey, D., Ellis-Chadwick, F., Mayer, R., Johnston, K. 2009).

- Internet Marketing (also known as eMarketing, Web Marketing, or Digital Marketing) is an all-inclusive term for marketing products and/or services online - and like many allinclusive terms, internet marketing means different things to different people. (Ward, 2016)

- Digital marketing, the promotion of products or brands via one or more forms of electronic media, differs from traditional marketing in that it uses channels and methods that enable an organization to analyze marketing campaigns and understand what is working and what isn't - typically in real time. (Source: sas.com)

Traditional Marketing involves collecting data through the process of market research and then analyzing the same to help understand the audiences better. The digital nature of the Internet technology provides a comprehensive and detailed insight into the characteristics of consumers and their behaviour in the electronic environment. (Batinić, 2015) This information has transformed the way business decisions are being made. The impact of each and every marketing initiative can be studied in real-time along with being customized for each and every customer.

\section{Objectives of the Study}

The major objectives of the present study are to

- To understand the concept of digital marketing

- To examine the characteristics of a successful digital marketing campaign

- To analyze the role of digital marketing in today's tourism industry 


\section{Characteristics of a Successful Digital Marketing Campaign}

Post understanding what digital marketing is all about, it is also important to understand the top six characteristics of successful digital marketing campaigns:

\section{- Quality Website}

A quality website today is a prerequisite before establishing a business online. It not only helps your business transcend geographical boundaries to reach newer prospects, but also work as digital destinations for your audiences who can access it $24 \times 7$ !

\section{- Strong Social Media presence}

Social Media platforms like Facebook, Twitter, LinkedIn, Instagram enable businesses to reach out and talk directly to their users. Presence on these platforms not only helps brands to establish credibility, improve customer services but also provides insights on what your customers are up to.

\section{- Search Engine Optimization}

SEO is an integral part of digital marketing today. The online ranking of a business on various search engines determines the online popularity and helps increase website visits. There is a lot of misconception that SEO efforts would lead to immediate results. It is important to understand that SEO is an ongoing process and takes time to show results. Businesses need to ensure that a dedicated team works on ensuring that both on-page and off-page SEO initiatives are undertaken.

\section{- Email Marketing}

Email Marketing isn't all about bombarding the inbox of your audiences with emails. It needs to be planned and executed well to ensure maximum returns. Sending personalized emails to users increases the chances of getting instant replies along with showing that a business cares. Customize offers and communication for various user groups based on where they lie in your business relationship cycle.

\section{- Engaging Content}

Content used across various online platforms should lead to increased engagement rates. Businesses need to ensure that they post relevant content across various platforms at the right time. Blogging is an excellent way to engage with audiences and move beyond than just selling products.

\section{- Mobile-Friendly}

Everything that a business does digitally today should be mobile friendly. Majority of online users today access the internet on their mobile phones and this should reflect in every aspect of online marketing considerations.

\section{Digital Marketing and Tourism Industry}

The tourism industry includes all the people, activities, and organizations involved in providing services for people on holiday, for example hotels, restaurants, and tour guides. Before the launch of digital marketing, the role of people who rendered these services was indispensible to 
the success of the business. With the launch of the internet, newer modes of marketing the various services to the target audiences have evolved. The tourism industry, in particular, has been disrupted as a whole with the rapid development of the internet. Users purchase services related to tourism online at the click of a button while comparing amongst businesses from all over the world. In order to compete and succeed digitally, the most relevant digital marketing activities include:

\section{- Quality Website}

'Marketing experts must come up with attractive websites, find a way to attract customers to visit the web site, keep them there for a while and make them frequently come back to their website.' (Kotler, P., Bowen, T. John., Makens, C. James 2010). This is especially true for businesses which are only present online like the tourism industry. Websites work as digital destinations for the audiences wherein a business can define their brand's experience. It is very important to keep the website content concise and ensure that the USPs are clearly visible. A good website should have all the services clearly listed down along with the relevant information. Adding highresolution images of various services being offered like hotel rooms, spa etc. will enable the users to take an informed decision. Users tend to read webpage as compartmentalized chunks of information by swiping their eyes from left to right, and then continue on down the page in an Fshaped pattern, skipping a lot of text in between. The best strategy is to break up long articles into sections so that users can easily skim down the page. It is also important to ensure that there is enough breathing space around the various images, texts and buttons on the website. Adequate spacing between elements on a page allows for a more enjoyable reading experience and allows time to focus on the individual pieces of a page without being overwhelmed by everything else around it. A lot of websites open the price lists, menus and packages in a new window to avoid disrupting the current experience of the users. The website must be built in a way that it allows the users to make a purchase without the need of any kind of assistance. It must be updated regularly keeping in view the changing customers' needs and preferences. The navigation tab should have a clear option for deals/packages to avoid an increase in the bounce rate. A good website represents the quality the business stands for and thus it should be developed and maintained keeping in mind the functionality of the industry.

\section{- Strong Social Media Presence}

Social Media is a new marketing tool that allows you to get to know your customers and prospects in ways that were previously not possible. This information and knowledge must be paid for with output of respect, trustworthiness, and honesty (Marjorie Clayman). The most relevant social media platforms for a tourism business include the following:
Facebook
$>$ Instagram
$>$ Twitter
$>$ LinkedIn
$>$ YouTube

Presence on these platforms is not just about promoting the latest packages and facilities; it is much more than that. A user will not avail the services on a daily basis so it is essential that a business becomes a part of the conversation users are having on these platforms. Focussing on posting content which adds value to the audiences' lives will help improve the engagement rate. 
Ixigo uploaded a simple video of travel hacks and it proved to be one of the most successful digital marketing campaigns of that year. Lastly, a brand shouldn't consider all these platforms as one. Each of them comes with its own set of USPs. Facebook and Instagram should be the top two platforms a tourism business.

\section{- Search Engine Optimization}

SEO plays a very important role in determining the website traffic. The businesses need to ensure that equal attention is paid to both on-page and off-page SEO activities. Use of 'Keyword Planner' to find the most relevant keywords for the tourism business is the first step towards effective SEO. Google, the biggest search engine, understands synonyms so keywords must be carefully chosen. The focus should be on creating quality backlinks rather than just increasing their numbers. Usage of long-tailed keywords such as 'best holiday package India' shall lead to more conversions rather than short-tailed keywords.

\section{- Email Marketing}

'The use of email marketing creates the opportunity to offer any potential interested guest to arrive at the right time at the minimum cost, and the results of such activities must be measurable, which creates a basis for decisions on future marketing activities.' (Kotler, P., Koller, K.L. 2008). Email Marketing enables users to know about the latest offers by the hotels, special deals on holiday packages, membership clubs, room availability and so much more. Transactional emails are sent to users to keep them updated about the status of their bookings. Emails are also a very good way of keeping the relationship going with the customers post the transaction has been completed. Special mailers are sent to customers on their birthdays and anniversaries by offering a special price on the services. This provides an incentive to the customers to make a purchase while visiting the competitors.

\section{- Content}

Content is the essence of digital marketing. Good quality content must be engaging and add value to the everyday lives of the audiences. According to socialmedia.com, "There's no secret formula to successfully engaging with your audience on social media, but applying 'The 80/20 Rule' should always be a big part of your social media strategy. It simply comes down to this: use just $20 \%$ of your content to promote your brand, and dedicate $80 \%$ to content that really interests your audience and engages them in conversations." In the tourism industry, videos and infographics are an interactive content type to get noticed and engage the users.

\section{- Mobile-Friendly}

There are 6.8 billion people on the planet, only 3.5 billion use a toothbrush, whilst 4 billion of them own a mobile phone, most of which are smartphones (Hubspot). The website, app, updates on social media, emails, SEO or any other aspect of digital marketing, being mobile-friendly is a prerequisite in today's times.

\section{Conclusion}

Digital Marketing today is all about using the internet technologies to reach out to existing and newer audiences and engage with them. Today digital marketing has disrupted industries and changed the way businesses reached out to customers. The main difference between traditional 
and digital marketing is the latter's ability to track data about user behaviour and campaign performance in real-time. In the tourism industry, the disruption was felt few years ago and has transformed the way businesses reach out to users. For any business to be successful digitally in the tourism industry, the above mentioned six points- quality website, SEO, Email marketing, Presence on social media, content, mobile-friendly play a very crucial role.

\section{References}

[1] Batinić, "Role and importance of internet marketing in modern hotel industry". Journal of Process Management - New Technologies, International, Vol. 3, No. 3, pp.34-38, 2015.

[2] Chaffey, D., Ellis-Chadwick, F., Mayer, R., Johnston, K. (2009). Internet Marketing: Strategy, Implementation and Practice. 4th Edition. Prentice Hall.

[3] Strauss, J., Frost, R. (2009). E-Marketing. 5th Edition. Pearson Prentice Hall. Strauss

[4] Judy (2003). "E-Marketing, 3rd edition", ND-AMA - School of Marketing.

[5] Lilien, G. L., Rangaswamy, A., De Bruyn, A. (2007). Principles of Marketing Engineering.

[6] Miller, M. (2011). The Ultimate Web Marketing Guide, Pearson Education

*Corresponding author.

E-mail address: gurneetkaur29@gmail.com 